\title{
Microsatellites Reveal High Population Viscosity and Limited Dispersal in the Ant Formica paralugubris
}

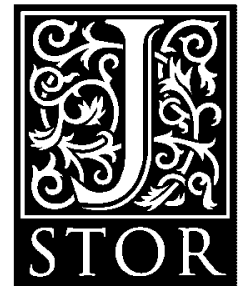

\author{
Michel Chapuisat, Jerome Goudet, Laurent Keller
}

Evolution, Volume 51, Issue 2 (Apr., 1997), 475-482.

\section{Stable URL:}

http://links.jstor.org/sici?sici=0014-3820\%28199704\%2951\%3C475\%3AMRHPVA\%3E2.0.CO\%3B2-P

Your use of the JSTOR archive indicates your acceptance of JSTOR's Terms and Conditions of Use, available at http://www.jstor.org/about/terms.html. JSTOR's Terms and Conditions of Use provides, in part, that unless you have obtained prior permission, you may not download an entire issue of a journal or multiple copies of articles, and you may use content in the JSTOR archive only for your personal, non-commercial use.

Each copy of any part of a JSTOR transmission must contain the same copyright notice that appears on the screen or printed page of such transmission.

Evolution is published by Society for the Study of Evolution. Please contact the publisher for further permissions regarding the use of this work. Publisher contact information may be obtained at http://www.jstor.org/journals/ssevol.html.

Evolution

(C1997 Society for the Study of Evolution

JSTOR and the JSTOR logo are trademarks of JSTOR, and are Registered in the U.S. Patent and Trademark Office. For more information on JSTOR contact jstor-info@umich.edu.

(C)2002 JSTOR 


\title{
MICROSATELLITES REVEAL HIGH POPULATION VISCOSITY AND LIMITED DISPERSAL IN THE ANT FORMICA PARALUGUBRIS
}

\author{
Michel Chapuisat, 1,2 Jérôme Goudet, ${ }^{2}$ and Laurent Keller ${ }^{2}$ \\ ${ }^{1}$ Musée de Zoologie, P.O. Box 448, 1000 Lausanne 17, Switzerland \\ E-mail: Michel.Chapuisat@izea.unil.ch \\ ${ }^{2}$ Institut de Zoologie et d'Ecologie Animale, University of Lausanne, 1015 Lausanne, Switzerland
}

\begin{abstract}
We used microsatellites to study the fine-scale genetic structure of a highly polygynous and largely unicolonial population of the ant Formica paralugubris. Genetic data indicate that long-distance gene flow between established nests is limited and new queens are primarily recruited from within their natal nest. Most matings occur between nestmates and are random at this level. In the center of the study area, budding and permanent connections between nests result in strong population viscosity, with close nests being more similar genetically than distant nests. In contrast, nests located outside of this supercolony show no isolation by distance, suggesting that they have been initiated by queens that participated in mating flights rather than by budding from nearby nests in our sample population. Recruitment of nestmates as new reproductive individuals and population viscosity in the supercolony increase genetic differentiation between nests. This in turn inflates relatedness estimates among worker nestmates $(r=0.17)$ above what is due to close pedigree links. Local spatial genetic differentiation may favor the maintenance of altruism when workers raise queens that will disperse on foot and compete with less related queens from neighboring nests or disperse on the wing and compete with unrelated queens.
\end{abstract}

Key words.-Ants, dispersal, Formica, genetic differentiation, microsatellite, population viscosity, queen number, relatedness, social evolution, social insects.

Received June 24, 1996. Accepted October 17, 1996.

The existence of sterile individuals in social insect colonies poses an evolutionary paradox, namely the difficulty of perpetuating sterility by natural selection when bearers of this trait leave no offspring. An important contribution to the resolution of this puzzle has been provided by Hamilton (1963, 1964a,b), who showed that individuals can pass on copies of their genes to the next generation not only by producing offspring, but also by helping nondescendent kin, such as siblings.

Colonies of social insects typically consist of related individuals, a necessary condition for kin selection to operate. However, nests of some ant and wasp species contain a high number of queens, which has the effect that nestmates are only distantly related (e.g., Sturtevant 1938; Queller et al. 1988; Hölldobler and Wilson 1990, pp. 186-188; Rosengren et al. 1993; Ross 1993; Keller 1995; Crozier and Pamilo 1996, pp. 108-135). Moreover, some polygynous ant species form unicolonial populations in which individuals move freely between nests. This absence of distinct colony boundaries may result in levels of genetic relatedness close to or indistinguishable from zero (Hölldobler and Wilson 1990, p. 187; Bourke and Franks 1995, pp. 282-285). Maintenance of reproductive altruism in colonies with very low relatedness provides a special difficulty for the theory of kin selection (Hamilton 1964b, 1972; Nonacs 1988; Keller 1995). Therefore, persistence and ecological success of unicolonial species constitute an important evolutionary problem (Hölldobler and Wilson 1977; Crozier 1979; Bourke and Franks 1995, p. 283; Crozier and Pamilo 1996, p. 143).

Hamilton (1964b) pointed out that limited dispersal of individuals from their birth place results in population genetic "viscosity." This induces genetic differentiation between geographically distant groups and consequently increases relatedness among neighbors. Therefore, Hamilton proposed that population viscosity may favor the evolution of altruism.
Since species with many queens per nest frequently produce new nests through colony budding (Keller 1991), this may lead to population viscosity and possibly maintain reproductive altruism if subsequent gene flow between nests is restricted. Population viscosity has indeed been reported in a number of polygynous social insects species, including wood ants (Pamilo 1983; Pamilo and Rosengren 1984).

The idea that population viscosity promotes reproductive altruism, however, has been challenged by theoretical studies that show that the outcome depends critically on population density regulation and dispersal processes. If density regulation and dispersal operate with similar intensities, and over the same geographical scale, the effect of increased relatedness between neighbors due to viscosity is exactly cancelled out by the effect of increased competition between neighboring kin (Pollock 1983; Queller 1992, 1994; Taylor 1992a,b; Wilson et al. 1992). However, if dispersal and density regulation operate over different spatial scales (Kelly 1992, 1994), if there is stochastic variation in the genetic composition of groups formed by budding (Goodnight 1992), or if altruism occurs among offspring before the dispersal stage (Taylor 1992a), then genetic variation among groups resulting from population viscosity may still promote the evolution of altruism. Overall, these theoretical studies concur that the effect of population viscosity on the evolution and maintenance of altruism depends on the precise relationship between density regulation and dispersal pattern.

A better understanding of the evolution and maintenance of insect colonies with high queen number requires data on dispersal, population regulation, and genetic structure at both nest and population levels. The aim of the present study was to provide detailed information on the genetic structure of a highly polygynous (many queens per nest) and polydomous (many interconnected nests per colony) population of the wood ant Formica paralugubris. This taxon has been recently 


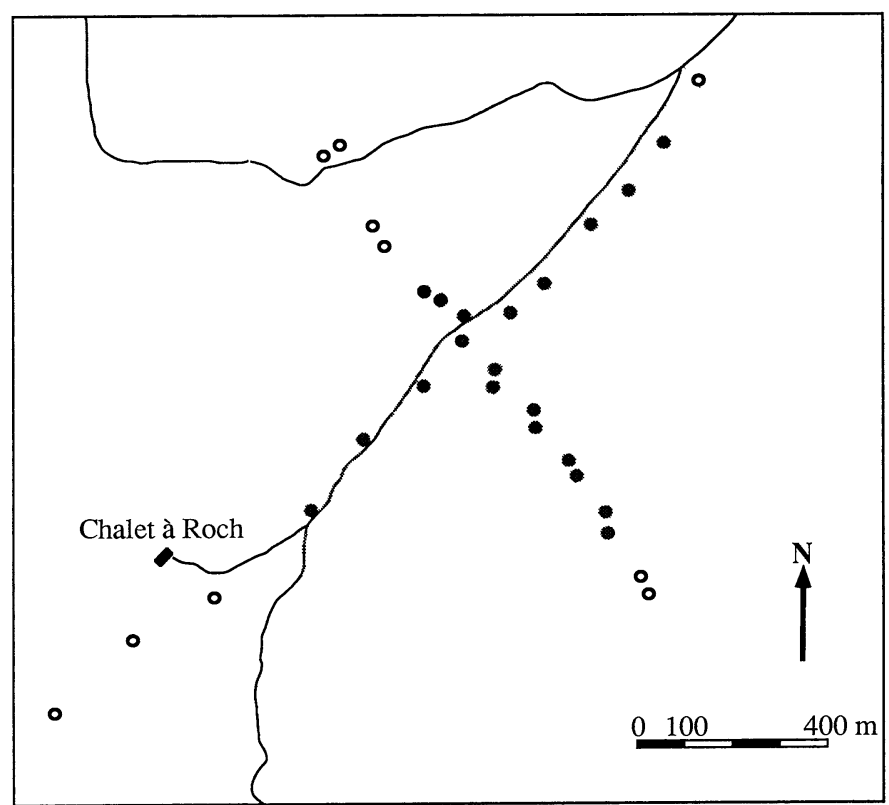

FIG. 1. Map of the study area at the "Chalet à Roch" in the Jura Mountains, Switzerland. The supercolony is indicated by the shaded area. Filled circles: sampled nests belonging to the supercolony ( $n$ $=20$ ). Empty circles: sampled nests out of the supercolony ( $n=$ 10).

described as a new species (Seifert 1996). It was previously referred to as Formica lugubris (e.g., Cherix 1980) or F. lugubris type B (Pamilo et al. 1992; Chapuisat 1996).

In the study population, direct observations revealed that nests contain about 1000 queens (Cherix 1980, 1983; Chapuisat, pers. obs.) and a study using allozyme electrophoresis showed that many queens actually reproduce (Pamilo et al. 1992). In the center of the study area, nest density is very high and there is no physical barrier between nests. About 1200 nests are connected by trails to form a supercolony that extends over $0.7 \mathrm{~km}^{2}$. The limits of the supercolony had been determined previously, using trails connecting nests and aggression tests (Gris and Cherix 1977; Cherix 1980; Fig. 1). Very high queen number and intermixing of individuals between nests will tend to decrease genetic relatedness among nestmates.

Young males and females exhibit two alternative dispersal strategies in $F$. paralugubris (Cherix et al. 1991). On the one hand they mate in their natal nest and females either remain there or disperse on foot to neighboring nests. Such a mating system tends to restrict gene flow between distant nests and increase population viscosity. On the other hand, males and females depart on mating flights and congregate on open meadows where they mate (Cherix et al. 1993). After mating, young queens may either parasitize the nest of another ant species (Kutter 1977, p. 272; Keller and Passera 1989) or seek adoption in an established conspecific colony (Fortelius et al. 1993). Successful infiltration of queens into foreign nests tends to homogenize allele frequencies in the population and reduce population viscosity.

We used microsatellite polymorphism to assess population viscosity, dispersal processes, and genetic relatedness among nestmates. We also tested whether nests within and outside of the supercolony differed in their social organization and genetic structure.

\section{Materials AND Methods}

\section{Sampling}

Workers were collected from 30 nests located within and outside of the supercolony, along two transects of 1.2 and $1.9 \mathrm{~km}$ (Fig. 1). This population is located near the Chalet à Roch in the Swiss Jura Mountains (Cherix 1980). All the nests included in the present study belong to $F$. paralugubris (Seifert 1996) and not to the sympatric sibling species $F$. lugubris, which has been occasionally found in the area surrounding the supercolony. The species was unambiguously identified by the study of morphological characters of workers (B. Seifert, pers. comm., 1995) and by aggression tests between workers from each sampled nest and workers from other nests of both species (Le Moli and Mori 1986; Chapuisat unpubl. data). Voucher specimens have been deposited in the Museum of Zoology, Lausanne, Switzerland.

\section{Microsatellite Typing}

Workers were stored in absolute ethanol until DNA extraction by proteinase K/SDS digestion and phenol-chloroform purification (Sambrook et al. 1989). Four microsatellites loci were analyzed using primers and methods described in Chapuisat (1996). Each locus had between four and 12 alleles yielding an expected heterozygosity ranging between 0.21 and 0.85 , under the assumption of Hardy-Weinberg proportions (Chapuisat 1996). Progeny studies confirmed that the four loci are unlinked and that alleles are inherited in a Mendelian fashion (Chapuisat, unpubl.). In total, 264 individuals were genotyped at loci FL12 and FL21 (eight to 10 workers from each of the 30 nests) and 226 at loci FL20 and FL29 (six to 10 workers from each of the 30 nests). To check that genotypes were assessed correctly, 50 individuals were analyzed a second time with $0.02 \mu \mathrm{L}$ of ${ }^{33} \mathrm{P}$-dATP per reaction instead of $0.05 \mu \mathrm{L}$ of ${ }^{35} \mathrm{~S}$-dATP, because the use of ${ }^{33} \mathrm{P}$-dATP results in stronger bands that are easier to score.

\section{Statistical Methods}

Genetic differentiation was quantified using Wright's fixation indices. These indices partition the reduction in heterozygosity of individuals relative to the total population $\left(F_{\text {IT }}\right)$, within subpopulations $\left(F_{\text {IS }}\right)$, and between subpopulations $\left(F_{\mathrm{ST}}\right)$ (e.g., Hartl and Clark 1989, pp. 293-294). Nests were treated as subpopulations, workers as individuals within these subpopulations, and the whole sample of nests as the total population. These hierarchical units of analysis are justified because many queens reproduce in each nest, and therefore nestmate workers constitute subpopulations rather than simple families. The variance component method developed by Cockerham $(1969,1973)$ and Weir and Cockerham (1984) was used to obtain values of the three $F$-statistics. Calculations were carried out using the PC computer program FSTAT vers. 1.2 (Goudet 1995).

Standard errors of $F$-statistics were obtained by jackknifing over nests. Significant deviations from zero were assessed using permutation tests (Excoffier et al. 1992; Goudet 1995). 
TABLE 1. $F$-statistics when nests are treated as subpopulations. Deviation from zero: $* P<0.05,{ }^{* *} P<0.01,{ }^{* * *} P<0.001$ (permutation test).

\begin{tabular}{lccl}
\hline \hline Locus & $F_{\mathrm{ST}} \pm \mathrm{SE}$ & $F_{\mathrm{IS}} \pm \mathrm{SE}$ & \multicolumn{1}{c}{$F_{\mathrm{IT}} \pm \mathrm{SE}$} \\
\hline FL12 & $0.07 \pm 0.02 * * *$ & $-0.02 \pm 0.04$ & $0.05 \pm 0.04 *$ \\
FL20 & $0.08 \pm 0.02 * * *$ & $0.07 \pm 0.03 *$ & $0.14 \pm 0.03 * * *$ \\
FL21 & $0.09 \pm 0.02 * * *$ & $-0.03 \pm 0.07$ & $0.06 \pm 0.06$ \\
FL29 & $0.13 \pm 0.03 * * *$ & $-0.04 \pm 0.06$ & $0.10 \pm 0.05 * *$ \\
All loci: & $0.09 \pm 0.01 * * *$ & $0.01 \pm 0.03$ & $0.10 \pm 0.02 * * *$ \\
\hline
\end{tabular}

The distributions of the null hypotheses $\left(F_{X Y}=0\right)$ were obtained from 5000 statistics estimated from permuted datasets and tested against the alternative hypotheses $\left(F_{\mathrm{XY}}>\right.$ $0)$. The appropriate permutation unit for $F_{\text {IS }}$ was alleles, which were permuted among individuals within nests. For $F_{\mathrm{ST}}$, since alleles within individuals may not be independent, the appropriate permutation unit was genotypes, which were permuted among nests. For $F_{\mathrm{IT}}$, alleles were permuted among nests.

Population viscosity was investigated by plotting $F_{\mathrm{ST}}$ coefficients between pairs of nests against geographic distances (Slatkin 1993). The significance of the Pearson correlation coefficient between genetic differentiation and geographic distance was assessed with Mantel tests when the matrix was symmetrical (Mantel 1967; Manly 1985, pp. 176-192, 1991, pp. 112-140). When an asymmetrical matrix precluded the use of a Mantel test, the significance of the Pearson correlation coefficient was tested with Bartlett chi-square statistics, after checking that variables were normally distributed.

Relatedness $(r)$ is an estimate of the probability of gene sharing among nestmates beyond the baseline probability set by the gene's frequency in the population (e.g., Bourke and Franks 1995, pp. 14-38; Crozier and Pamilo 1996, pp. 3639). Relatedness was assessed by the method of Queller and Goodnight (1989), which is based on Grafen's (1985) relatedness coefficient. Calculations were performed with the computer program Relatedness 4.2b (Goodnight 1994), weighting nests equally. Standard errors of relatedness estimates were obtained by jackknifing over nests. Significant deviation from zero was tested with one-tailed $t$-tests with degrees of freedom equal to the number of nests minus one. Note that relatedness is associated with $F$-statistics by the formula $r=2 F_{\mathrm{ST}} /\left(1+F_{\mathrm{IT}}\right)$ (Hamilton 1972; Queller and Goodnight 1989).

Several studies have shown that estimates of genetic relatedness among nestmates are inflated by spatial genetic differentiation and inbreeding (Pamilo 1984, 1985, 1989). Therefore, we used Pamilo's $(1984,1985)$ “imbreeding cor- rection" to obtain an estimate of genetic relatedness $\left(r^{*}\right)$ that is rid of this effect and reflects the number of reproducing individuals present in the nest:

$$
r^{*}=\left[r-2 F_{\mathrm{IT}} /\left(1+F_{\mathrm{IT}}\right)\right] /\left[1-2 F_{\mathrm{IT}} /\left(1+F_{\mathrm{IT}}\right)\right] .
$$

\section{RESUlTS}

\section{Nests and Population Genetic Structure}

$F_{\text {ST }}$ estimated over all loci was significantly greater than zero, indicating that nests are genetically differentiated in the population we studied (30 nests along two transects of 1.2 and $1.9 \mathrm{~km}$; Table 1, Fig. 1). Single-locus estimates of $F_{\mathrm{ST}}$ were similar for the four loci, all being significantly greater than zero (Table 1).

$F_{\text {IT }}$ was also significantly greater than zero when estimated over all loci and for three of the individual loci, confirming nonrandom mating at the population level (Table 1). The estimate of $F_{\text {IT }}$ at locus FL21 was not significantly different from zero, but the statistical power of this locus is low due to its low level of genetic diversity (four alleles with one allele at a frequency of 0.88 , expected heterozygosity 0.21 ; Chapuisat 1996).

$F_{\text {IS }}$ was not significantly different from zero when estimated over all loci, and for three of the individual loci (Table 1). This result is consistent with limited dispersal and random mating among sexuals within the nest. The $F_{\text {IS }}$ value was positive and marginally significant for FL20, possibly due to the difficulty in scoring some very long alleles at this locus.

Nests within and outside the supercolony do not differ significantly in their genetic structure, as shown by $F$-statistics with largely overlapping confidence intervals when nests within and outside of the supercolony were considered separately and together (Table 2 ). In particular, $F_{\mathrm{ST}}$ was not greater when calculated over all nests than over separate groups of nests within or outside of the supercolony. This indicates that there is no extra-genetic differentiation between these two groups of nests.

The only detectable difference between nests within and outside of the supercolony was the degree of isolation by distance. Strong population viscosity was detected within the supercolony. Genetic differentiation between pairs of nests was significantly correlated with geographical distance (Fig. 2A, Mantel test: $n=20$, matrices correlation $=0.50, P<$ $0.0002)$. Moreover, there was no discontinuity in the distribution of paired $F_{\mathrm{ST}}$ against distance, indicating a continuous process of isolation by distance (Slatkin 1993).

In sharp contrast, no correlation between genetic differentiation and geographic distance was detected for pairs of

TABLE 2. F-statistics when nests within and outside of the supercolony are analyzed separately or together, treating nests as subpopulations; $95 \%$ confidence intervals are given in parentheses.

\begin{tabular}{|c|c|c|c|}
\hline & $F_{\mathrm{ST}} \pm \mathrm{SE}$ & $F_{\mathrm{IS}} \pm \mathrm{SE}$ & $F_{\mathrm{IT}} \pm \mathrm{SE}$ \\
\hline Nests within the supercolony & $\begin{array}{c}0.09 \pm 0.02 \\
(0.05 \text { to } 0.12)\end{array}$ & $\begin{array}{c}0.00 \pm 0.04 \\
(-0.09 \text { to } 0.10)\end{array}$ & $\begin{array}{c}0.09 \pm 0.03 \\
(0.03 \text { to } 0.15)\end{array}$ \\
\hline Nests outside of the supercolony & $\begin{array}{c}0.09 \pm 0.02 \\
(0.03 \text { to } 0.14)\end{array}$ & $\begin{array}{c}0.01 \pm 0.05 \\
(-0.11 \text { to } 0.13)\end{array}$ & $\begin{array}{c}0.09 \pm 0.03 \\
(0.02 \text { to } 0.17)\end{array}$ \\
\hline All nests & $\begin{array}{c}0.09 \pm 0.01 \\
(0.07 \text { to } 0.11)\end{array}$ & $\begin{array}{c}0.01 \pm 0.03 \\
(-0.06 \text { to } 0.07)\end{array}$ & $\begin{array}{c}0.10 \pm 0.02 \\
(0.05 \text { to } 0.14)\end{array}$ \\
\hline
\end{tabular}



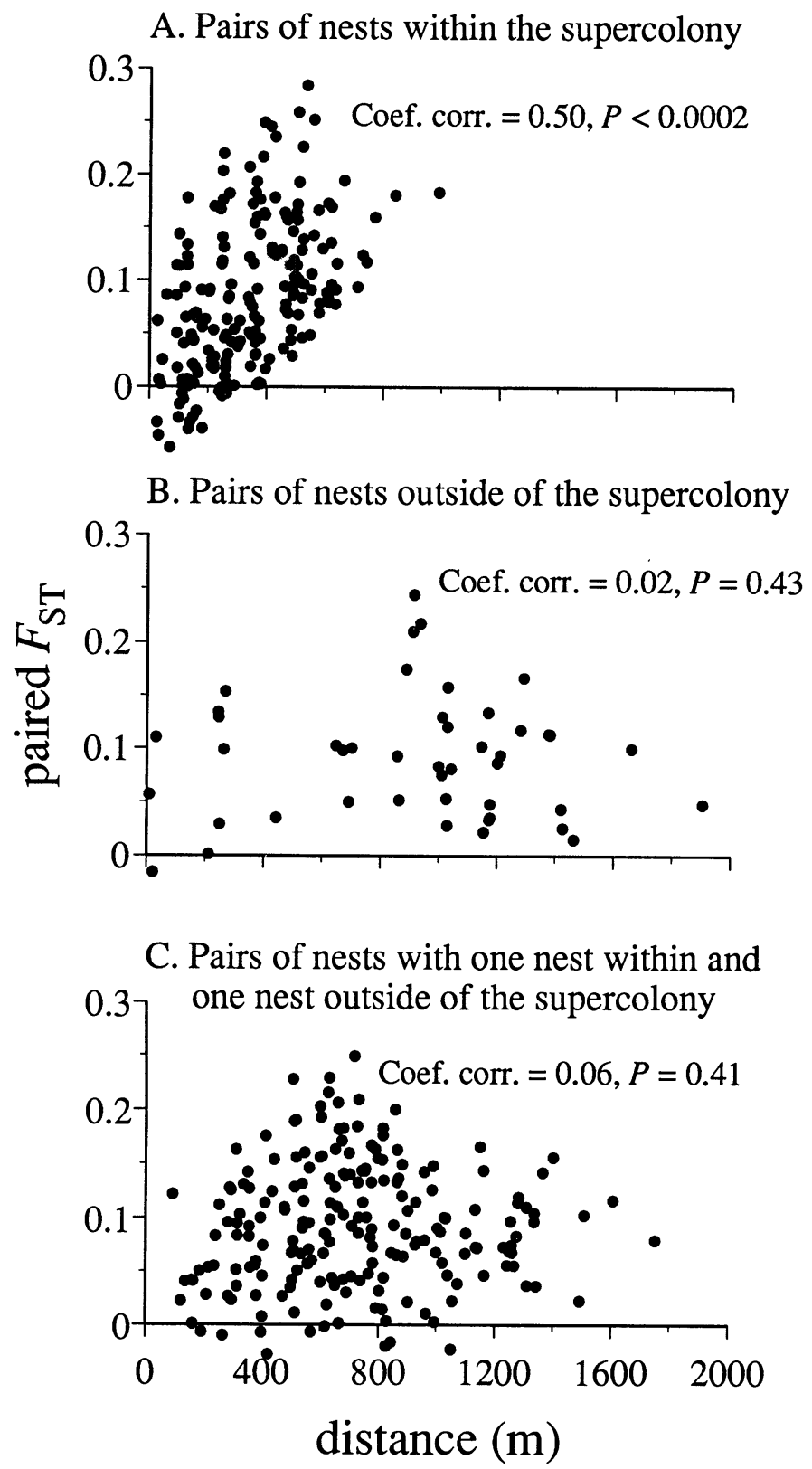

FIG. 2. Relationship between genetic differentiation $\left(F_{\mathrm{ST}}\right.$ for pairs of nests) and geographic distance.

nests located out of the supercolony (Fig. 2B, Mantel test: $n$ $=10$, matrices correlation $=0.02, P=0.43$ ). Moreover, no viscosity was detected for pairs of nests when one nest was outside of the supercolony and the other belonged to it (Fig. 2C, Bartlett chi-square: matrices correlation $=0.06, P=$ 0.41 ). These results suggest that nests surrounding the supercolony are not genetically more similar to close nests than to distant nests in our sample population.

\section{Dispersal}

Gene flow among nests can be mediated by both queens and males. Below, we consider in turn the two extreme cases in which gene flow is mediated by either females or males only.
Assuming that migration occurs at random among all sampled nests (island model), that nests are at migration/drift equilibrium, and that migration rate is low, one can estimate the number of migrants among polygynous nests from the $F_{\mathrm{ST}}$ value. Wright (1943) showed that $F_{\mathrm{ST}}=1 /\left(4 N_{e} m+1\right)$, where $N_{e}$ is the effective population size and $m$ the migration rate. Thus, the number of migrants between nests is equal to $N_{e} m$.

With the observed value of 0.09 for $F_{\mathrm{ST}}$, Wright's formula yields an estimate of 2.5 migrants per generation. This value should of course be considered with caution since it depends on the above assumptions, which might not hold for all nests. Especially, migration is certainly not occurring at random among nests of the supercolony. However, the important point is that effective gene flow between distant nests is very restricted. For example, if gene flow is mediated through females only and if nests contain 1000 queens with a mean longevity of two years (a value typical for queens of polygynous ant species; Keller and Passera 1990; Keller, unpubl.), an estimate of 2.5 migrants per generation implies that about $99.5 \%$ of the queens are recruited from within the nest.

Pamilo (1985) proposed a method for estimating the proportion of mating that occurs with nestmate versus alien males when all queens are recruited from within the nest. If one assumes that queens mate once, the rate of intranidal mating $(\alpha)$ can be estimated from the relatedness among workers $(r)$, the inbreeding coefficient $\left(F_{\mathrm{IT}}\right)$ and the effective number of queens $(n)$ by using the following equations of Pamilo (1985):

$$
r=\frac{4 n r_{1}[2 n+\alpha(n-1)]-\alpha(n-1)\left[4 n-2 \alpha n+\alpha^{2}(n-1)\right]}{2 n^{2}(3 n+1)-\alpha(n-1)\left\{6 n^{2}-n-[n-\alpha(n-1)]^{2}\right\}},
$$

where $r_{1}$ is given by:

$$
r_{1}=\left[0.75\left(1-F_{\mathrm{IT}}\right) /\left(1+F_{\mathrm{IT}}\right)\right]+\left[2 F_{\mathrm{IT}} /\left(1+F_{\mathrm{IT}}\right)\right] \text {. }
$$

With an approximation of 1000 queens per nest and the observed values of 0.17 for $r$ and 0.10 for $F_{\text {IT }}$, these equations estimate that $99.5 \%$ of the queens mate with nestmate males. This estimate is robust to variations in effective queen number. For instance, if one assumes that nests contain 500 or 100 reproductive queens, $\alpha$ decreases only to $99 \%$ and $95 \%$, respectively.

\section{Genetic Relatedness among Nestmate Workers}

Mean genetic relatedness among nestmate workers estimated over all loci was $0.17 \pm 0.02$, when measured with respect to the whole population (Table 3, Fig. 1). Each of the four microsatellite loci gave similar estimates, all of them being significantly greater than zero (Table 3 ).

Due to population viscosity within the supercolony, relatedness and $F_{\text {IT }}$ values were highly dependent on the geographical size of the population of reference (Fig. 3). If only a small population of reference with closely located nests within the supercolony was considered, $r$ and $F_{\text {IT }}$ were both very close to zero. When the population of reference was larger and included nests that were more distantly located, both $r$ and $F_{\text {IT }}$ increased. Interestingly, the estimate of relatedness "corrected for inbreeding" $r$ remained constant 
TABLE 3. Genetic relatedness among nestmate workers $(r)$ and "inbreeding corrected" relatedness $\left(r^{*}\right)$. Deviation from zero: * $P$ $<0.05$, ** $P<0.01$, *** $P<0.001$ (one-tailed $t$-test); $95 \%$ confidence intervals are given in parentheses.

\begin{tabular}{lcr}
\hline \hline & $r \pm \mathrm{SE}$ & $r^{*} \pm \mathrm{SE}$ \\
\hline All nests: & $0.13 \pm 0.04 * * *$ & $0.03 \pm 0.08$ \\
FL12 & $0.15 \pm 0.03 * * *$ & $-0.13 \pm 0.08$ \\
FL20 & $0.16 \pm 0.04 * * *$ & $0.06 \pm 0.14$ \\
FL21 & $0.24 \pm 0.04 * * *$ & $0.07 \pm 0.11$ \\
FL29 & $0.17 \pm 0.02 * * *$ & $-0.01 \pm 0.03$ \\
All loci: & $(0.12$ to 0.21$)$ & $(-0.08$ to 0.06$)$ \\
\multicolumn{4}{l}{ Nests within the supercolony: } \\
All loci: $\quad 0.16 \pm 0.03 * * *$ & $-0.01 \pm 0.05$ \\
\multicolumn{4}{l}{ Nests outside of the supercolony: } \\
All loci: & $0.17 \pm 0.04 * *$ & $(-0.11$ to 0.09$)$ \\
\multicolumn{2}{l}{} \\
& $(0.07$ to 0.26$)$ & $-0.01 \pm 0.07$ \\
\hline
\end{tabular}

and close to zero, whatever the population of reference (Fig. 3, Table 3). When measured for all nests and over all loci, $r^{*}$ was significantly smaller than $r$, as shown by nonoverlapping confidence intervals (Table 3; Weir 1996, p. 164).

When considered separately, nests located within and outside of the supercolony had very similar relatedness estimates with largely overlapping confidence intervals (Table 3).

\section{DisCUSSION}

Experimental studies have shown that in the highly polygynous ant $F$. paralugubris new queens can mate and stay in their natal nest or seek adoption in a foreign nest after a mating flight (Cherix et al. 1991). If queens were frequently successful in entering foreign nests after the mating flight, this would induce a rapid genetic homogenization of the population (Slatkin 1987). This is not the case in our study population, as indicated by the significant genetic differentiation among nests. Wright's island model suggests that there are relatively few migrants among nests compared to the large number of queens that are replaced yearly. Thus, most new reproductive individuals are recruited from within the nest. Accordingly, Pamilo's (1985) formulae estimate that about $99.5 \%$ of the queens mate with nestmate males. Lack of heterozygous deficit within nests suggests that nestmates mate together at random.

Two mechanisms might restrain successful infiltration of queens into foreign nests. First, workers may recognize foreign queens and selectively exclude them. Experimental introduction of young queens into nests does not support this hypothesis. Fortelius et al. (1993) found no significant difference in the acceptance rate of alien versus native queens that were introduced into nests in our study population. However, it should be noted that the survival rate of queens was determined two hours after introduction, and, therefore, executions of alien queens that may have occurred later (e.g., at the onset of oogenesis; Keller and Ross 1993) would not be detected. Second, mortality of queens attempting to join foreign nests may occur before they have a chance to enter the nest. Hence, high mortality of dispersing queens together with elevated number of queens that mate and stay in the

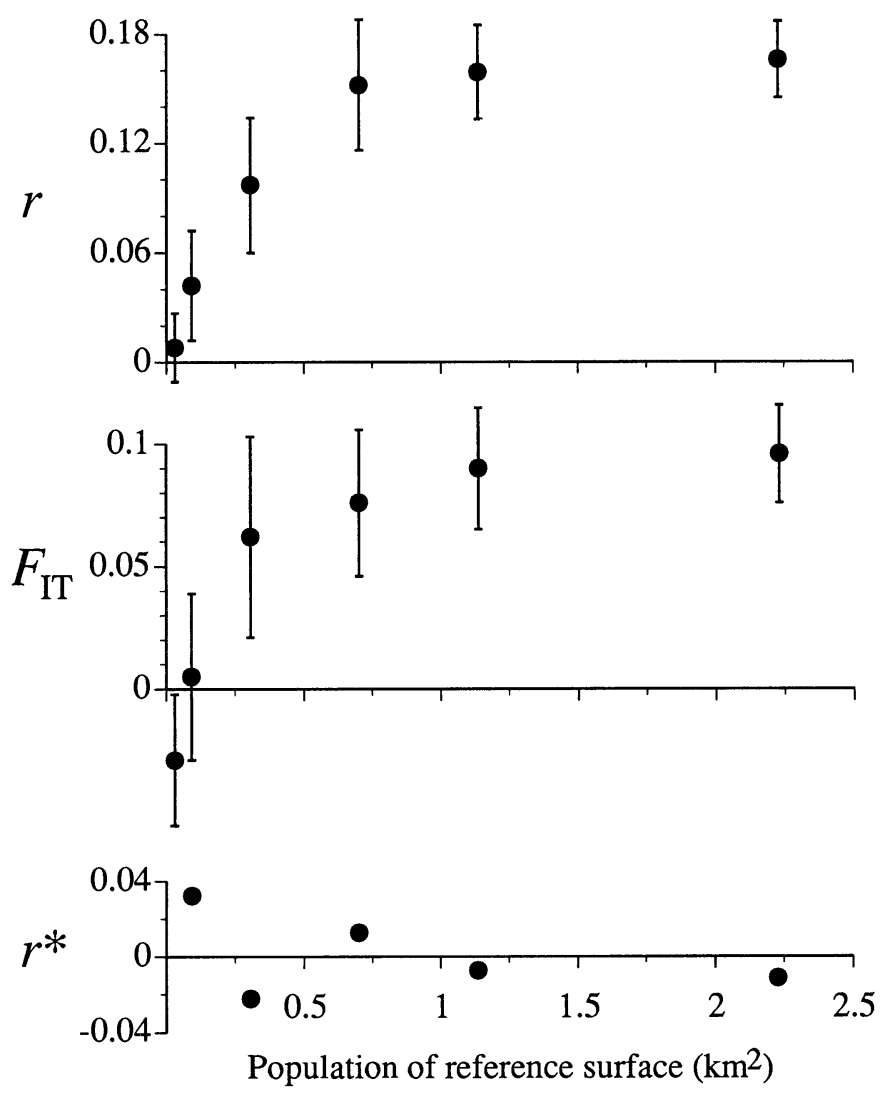

FIG. 3. Mean estimates ( \pm SE) of genetic relatedness among nestmate workers, $r$, fixation index, $F_{\mathrm{IT}}$, and "inbreeding corrected" relatedness, $r^{*}$, when measured with respect to a population of reference of variable size. The smallest population of reference includes five nests at the intersection of the transects. It is progressively enlarged until it covers the total studied area (see Fig. 1).

nest are probably the main factors responsible for the restricted gene flow between nests.

Pronounced population viscosity was detected within the supercolony. The continuous isolation by distance in the supercolony may be due to nest budding, dispersal of sexual individuals to closely located nests, or permanent connections between neighboring nests with ongoing exchange of workers. Due to the high nest density and intense competition with established nests, reproduction by budding is likely to be the main or even sole mode of formation of new nests in the supercolony. Newly founded nests will therefore tend to be genetically similar to the nest from which they originate. Workers of the study population have sometimes been observed transporting queens between neighboring nests, suggesting that gene flow between close nests might also be mediated by this means.

Significant microgeographic genetic differentiation has been reported in at least 11 other ant species (Halliday 1983; Pamilo 1983; Crozier et al. 1984; Pamilo and Rosengren 1984; Boomsma et al. 1990; Stille and Stille 1993; Herbers and Grieco 1994; Seppä and Pamilo 1995; Banschbach and Herbers 1996; Ross et al., unpubl. data cited in Ross and Keller 1995). Interestingly, all these species form polygynous colonies and most probably reproduce at least occasionally 
by nest budding. Among polygynous species in which microgeographic genetic differentiation was specifically investigated, it was not detected in only three of 14 species (Pamilo 1982 , 1983). Two of these are weakly polygynous and probably monodomous (without connections between nests), and the third is highly polygynous but was studied over a very small area. By contrast, significant microstructuring seems to be rare in monogynous ant species, where it has never been reported. Significant microgeographic genetic structure has been detected in several independent colony-founding wasp or bee species that tend to be philopatric (Metcalf 1980; Crozier et al. 1987; Ross and Matthews 1989; Davis et al. 1990; Blows and Schwarz 1991; Ross and Carpenter 1991; Queller et al. 1992).

Lack of population viscosity for nests surrounding the supercolony indicates that budding and exchange of individuals between nests is limited at the scale at which we sampled. Such a genetic structure is consistent with the idea that nests located outside of the supercolony originated from queens parasitizing the nest of another Formica species after a mating flight (Kutter 1977), rather than from buds of nearby nests in our sample population.

Apart from the occurrence of population viscosity, no difference in genetic structure between nests within and outside of the supercolony was detected. This suggests that the process of queen recruitment is similar in these two types of nests, with most new queens being recruited from within the nest after having mated with nestmate males.

Across the study population, limited dispersal of individuals increases genetic differentiation among nests. This in turn tends to boost relatedness among nestmates above what is due to close pedigree links. The relatedness among nestmate workers was 0.17 if all sampled nests were included in the population of reference. In sharp contrast, the relatedness between workers $\left(r^{*}\right)$ was close to zero when Pamilo's correction for inbreeding was used, a value reflecting the high number of queens coexisting in each nest. Interestingly, nests within and outside of the supercolony had similarly low levels of genetic relatedness, which indicates that both types of nests contain many queens.

As a result of viscosity within the supercolony, estimated relatedness among nestmate workers was strongly influenced by the size of the population of reference. Relatedness among workers decreased when smaller populations of reference were used, leading to an estimate of relatedness not significantly different from zero when only closely located nests within the supercolony were considered.

In a study of $F$. paralugubris that was conducted over a much larger scale than ours, Pamilo et al. (1992) obtained a relatively high relatedness estimate associated with a positive fixation index. Consequently, the "inbreeding corrected" relatedness was close to zero. These results are in close agreement with ours. The present study shows that marked genetic differentiation occurs at a much smaller geographic scale.

Together these results call for some caution when interpreting data on genetic relatedness in polygynous species. When microgeographic genetic differentiation occurs, estimates of relatedness are highly dependent on the scale of sampling, and relatedness measured within a neighborhood differs from that measured within the whole population (Cro- zier et al. 1984). For instance, values of inbreeding and relatedness will tend toward zero if the population of reference is small and includes only neighbor nests that have been formed by budding or are interconnected by gene flow. This might be the reason why very low values of genetic relatedness have been reported in some polygynous populations (Pamilo 1982; Pearson 1982, 1983; Kaufmann et al. 1992; Pamilo et al. 1992; Pearson and Raybould 1993; Seppä and Walin 1996).

Overall the dispersal strategies suggested by the present study have important implications with regard to the role of kin selection in highly polygynous insect societies. Taylor (1992a) suggested that viscosity may promote kin selection if altruism occurs among offspring before the dispersal stage. This almost certainly is the case in our population. Viscosity indicates that a fraction of queens successfully disperse to neighboring nests. These queens will tend to compete with less related individuals, thus providing kin-selected benefits to workers that have raised these queens. Moreover, our data also provide evidence of low frequency long-distance dispersal mediated by queens parasitizing the nest of other Formica species after a nuptial flight. Since these queens will generally compete with unrelated individuals this, again, will increase the inclusive fitness of workers that have contributed to the production of these queens. Because the patterns of dispersal and colony genetic structure that we report here are probably typical of many other highly polygynous ant species, our results suggest that kin selection may still be a significant selective force promoting altruistic behavior in highly polygynous insect societies.

\section{ACKNOWLEDGMENTS}

We thank W. D. Brown, J. H. Herbers, P. Pamilo, J. S. Pedersen, N. Perrin, D. C. Queller, K. G. Ross, J. A. Shykoff, and two anonymous reviewers for comments on the manuscript; D. Cherix for constant support; J. Hausser and P. Vogel for providing lab facilities; and B. Seifert for identifying ant specimens. This work was supported by the Fondation du $450 \mathrm{e}$ anniversaire of the University of Lausanne and the Swiss National Science Foundation (grants no. 31-35584.92, $31-36907.93,31-040828.94,31-43330.95$ and $31-43443.95)$.

\section{Literature Cited}

Banschbach, V. S., ANd J. M. Herbers. 1996. Complex colony structure in social insects. I. Ecological determinants and genetic consequences. Evolution 50:285-297.

Blows, M. W., AND M. P. SchWARz. 1991. Spatial distribution of a primitively social bee: Does genetic population structure facilitate altruism? Evolution 45:680-693.

Boomsma, J. J., A. H. Brouwer, and A. J. Van Loon. 1990. A new polygynous Lasius species (Hymenoptera Formicidae) from central Europe. II. Allozymatic confirmation of species status and social structure. Insectes Sociaux 37:363-375.

Bourke, A. F. G., AND N. R. Franks. 1995. Social evolution in ants. Princeton Univ. Press, Princeton, NJ.

Chapuisat, M. 1996. Characterization of microsatellite loci in Formica lugubris $B$ and their variability in other ant species. Mol. Ecol. 5:599-601.

CHERIX, D. 1980. Note préliminaire sur la structure, la phénologie et le régime alimentaire d'une super-colonie de Formica lugubris Zett. Insectes Sociaux 27:226-236.

. 1983. Pseudogynes (sécrétergates) et répartition des in- 
dividus à l'interieur d'une fourmilière de Formica lugubris Zett. (Hymenoptera: Formicidae). Insectes Sociaux 30:184-192.

Cherix D., D. Chautems, D. J. C. Fletcher, W. Fortelius, G. Gris, L. Keller, L. Passera, R. Rosengren, E. L. Vargo, and F. WALTER. 1991. Alternative reproductive strategies in Formica lugubris Zett. (Hymenoptera Formicidae). Ethol. Ecol. Evol. Spec. Iss. 1:61-66.

Cherix, D., D.J.C. Fletcher, D. Chautems, W. Fortelius, G. Gris, L. Keller, R. Rosegren, E. L. Vargo, and F. Walter. 1993. Attraction of the sexes in Formica lugubris Zett. (Hymenoptera: Formicidae). Insectes Sociaux 40:319-324.

COCKERHAM, C. C. 1969. Variance of gene frequencies. Evolution $23: 72-84$

- 1973. Analysis of gene frequencies. Genetics 74:679-700.

Crozier, R. H. 1979. Genetics of sociality. Pp. 223-286 in H. R. Hermann, ed. Social insects. Academic Press, New York.

Crozier, R. H., AND P. Pamilo. 1996. Evolution of social insect colonies: Sex allocation and kin selection. Oxford Univ. Press, Oxford.

Crozier, R. H., P. Pamilo, and Y. C. Crozier. 1984. Relatedness and microgeographic genetic variation in Rhytidoponera mayri, an Australian arid-zone ant. Behav. Ecol. Sociobiol. 15:143150.

Crozier, R. H., B. H. SMith, AND Y. C. Crozier. 1987. Relatedness and population structure of the primitively eusocial bee Lasioglossum zephyrum (Hymenoptera: Halictidae) in Kansas. Evolution 41:902-910.

Davis, S. K., J. E. Strassmann, C. Hughes, L. S. Pletscher, and A. R. Templeton. 1990. Population structure and kinship in Polistes (Hymenoptera, Vespidae): An analysis using ribosomal DNA and protein electrophoresis. Evolution 44:1242-1253.

Excoffier, L., P. E. Smouse, And J. M. Quattro. 1992. Analysis of molecular variance inferred from metric distances among DNA haplotypes: Application to human mitochondrial DNA restriction data. Genetics 131:479-491.

Fortelius W., R. Rosengren, D. Cherix and D. Chautems. 1993. Queen recruitment in a highly polygynous supercolony of Formica lugubris (Hymenoptera, Formicidae). Oikos 67:193-200.

GoODNIGHT, K. F. 1992. The effect of stochastic variation on kin selection in a budding-viscous population. Am. Nat. 140:10281040. TX. 1994. Relatedness 4.2b. Goodnight Software, Houston,

GoudET, J. 1995. FSTAT (vers. 1.2): A computer program to calculate F-statisics. J. Hered. 86:485-486.

Grafen, A. 1985. A geometric view of relatedness. Pp. 28-89 in R. Dawkins and M. Ridley, eds. Oxford surveys in evolutionary biology. Oxford Univ. Press, Oxford.

Gris, G., AND D. Cherix. 1977. Les grandes colonies de fourmis des bois du Jura (groupe Formica rufa). Mitt. Schweiz. Entomol. Gesell. 50:249-250.

HallidAY, R. B. 1983. Social organization of meat ants Iridomyrmex purpureus analysed by gel electrophoresis of enzymes. Insectes Sociaux 30:45-56.

Hamilton, W. D. 1963. The evolution of altruistic behavior. Am. Nat. 97:354-356.

. 1964a. The genetical evolution of social behaviour. I. J. Theor. Biol. 7:1-16.

. 1964b. The genetical evolution of social behaviour. II. J. Theor. Biol. 7:17-52.

- 1972. Altruism and related phenomena, mainly in social insects. Annu. Rev. Ecol. Syst. 3:193-232.

Hartl, D. L., AND A. G. Clark. 1989. Principles of population genetics. Sinauer, Sunderland, MA.

Herbers, J. M., AND S. Grieco. 1994. Population structure of Leptothorax ambiguus, a facultatively polygynous and polydomous ant species. J. Evol. Biol. 7:581-598.

HöllDOBLER, B., AND E. O. WILSON. 1977. The number of queens: An important trait in ant evolution. Naturwissenschaften 64:815.

. 1990. The ants. Springer, Berlin.

Kaufmann, B., J. J. Boomsma, L. Passera, and K. N. Petersen. 1992. Relatedness and inbreeding in a French population of the unicolonial ant Iridomyrmex humilis (Mayr). Insectes Sociaux 39:195-200.

KeLLER, L. 1991. Queen number, mode of colony founding and queen reproductive success in ants (Hymenoptera, Formicidae). Ethol. Ecol. Evol. 3:307-316.

. 1995. Social life: The paradox of multiple-queen colonies. Trends Ecol. Evol. 10:355-360.

Keller, L., AND L. Passera. 1989. Size and fat content of gynes in relation to the mode of colony founding in ants (Hymenoptera: Formicidae). Oecologia 80:236-240.

- 1990. Fecundity of ant queens in relation to their age and the mode of colony founding. Insectes Sociaux 37:116-130.

Keller, L., AND K. G. Ross. 1993. Phenotypic basis of reproductive success in a social insect: Genetic and social determinants. Science 260:1107-1110.

Kelly, J. K. 1992. Restricted migration and the evolution of altruism. Evolution 46:1492-1495.

1994. The effect of scale dependent processes on kin selection: Mating and density regulation. Theor. Popul. Biol. 46: 32-57.

KutTER, H. 1977. Hymenoptera, Formicidae. Insecta Helvetica, Schweizerischen Entomologischen Gesellschaft, Zürich, Switzerland.

Le Moli, F., AND A. Mori. 1986. The aggression test as a possible taxonomic tool in the Formica rufa group. Aggress. Behav. 12: 93-102.

ManLy, B. J. F. 1985. The statistics of natural selection on animal populations. Chapman and Hall, London.

. 1991. Randomization and Monte Carlo methods in biology. Chapman and Hall, London.

MANTEL, N. 1967. The detection of disease clustering and a generalized regression approach. Cancer Res. 27:209-220.

Metcalf, R. A. 1980. Sex ratios, parent-offspring conflict, and local competition for mates in the social wasps Polistes metricus and Polistes variatus. Am. Nat. 116:642-654.

NonACs, P. 1988. Queen number in colonies of social Hymenoptera as a kin-selected adaptation. Evolution 42:566-580.

Pamilo, P. 1982. Genetic population structure in polygynous Formica ants. Heredity 48:95-106.

- 1983. Genetic differentiation within subdivided populations of Formica ants. Evolution 37:1010-1022.

- 1984. Genotypic correlation and regression in social groups: Multiple alleles, multiple loci and subdivided populations. Genetics 107:307-320.

- 1985. Effect of inbreeding on genetic relatedness. Hereditas 103:195-200.

1989. Estimating relatedness in social groups. Trends Ecol. Evol. 4:353-355.

Pamilo, P., AND R. Rosengren. 1984. Evolution of nesting strategies of ants: Genetic evidence from different population types of Formica ants. Biol. J. Linn. Soc. 21:331-348.

Pamilo, P., D. Chautems, and D. Cherix. 1992. Genetic differentiation of disjunct populations of the ants Formica aquilonia and Formica lugubris in Europe. Insectes Sociaux 39:15-29.

PeArson, B. 1982. Relatedness of normal queens (macrogynes) in nests of the polygynous ant Myrmica rubra Latreille Evolution 36:107-112.

- 1983. Intra-colonial relatedness amongst workers in a population of nests of the polygynous ant, Myrmica rubra Latreille. Behav. Ecol. Sociobiol. 12:1-4.

Pearson, B., And A. F. Raybould. 1993. The effects of sampling and nest structure on relatedness in Myrmica rubra populations (Hymenoptera: Formicidae). Sociobiology 21:209-216.

Pollock, G. B. 1983. Population viscosity and kin selection. Am. Nat. 122:817-829.

Queller, D. C. 1992. Does population viscosity promote kin selection? Trends Ecol. Evol. 7:322-324.

1994. Genetic relatedness in viscous populations. Evol. Ecol. 8:70-73.

Queller, D. C., AND K. F. Goodnight. 1989. Estimating relatedness using genetic markers. Evolution 242:258-275.

Queller, D. C., J. E. Strassmann, And C. R. Hughes. 1988. 
Genetic relatedness in colonies of tropical wasps with multiple queens. Science 242:1155-1157.

1992. Genetic relatedness and population structure in primitively eusocial wasps in the genus Mischocyttarus (Hymenoptera: Vespidae). Journal of Hymenoptera Research 1:8189.

Rosengren, R., L. Sundström, and W. Fortelius. 1993. Monogyny and polygyny in Formica ants: the result of alternative dispersal tactics. Pp. 308-333 in L. Keller, ed. Queen number and sociality in insects. Oxford Univ. Press, Oxford.

Ross, K. G. 1993. The breeding system of the fire ant Solenopsis invicta: Effects on colony genetic structure. Am. Nat. 141:554576.

Ross, K. G., And J. M. Carpenter. 1991. Population genetic structure, relatedness, and breeding systems. Pp. 451-479 in K. G. Ross and R. W. Matthews, eds. The social biology of wasps. Cornell Univ. Press, Ithaca, NY.

Ross, K. G., AND L. KELLER. 1995. Ecology and evolution of social organization: insights from fire ants and other highly eusocial insects. Annu. Rev. Ecol. Syst. 26:631-656.

Ross, K. G., AND R. W. MatThews. 1989. Population genetic structure and social evolution in the specid wasp Microstigmus comes. Am. Nat. 134:574-598.

Sambrook, J., E. F. Fritsch, and T. Maniatis. 1989. Molecular Cloning. A laboratory manual. Cold Spring Harbor Laboratory Press, New York.

SEIFERT, B. 1996. Formica paralugubris nov. spec.-A sympatric sibling species of Formica lugubris from the western Alps (Insecta: Hymenoptera: Formicoidea: Formicidae). Reichenbachia 31:193-201.
SEPPÄ, P., AND P. PAMILO. 1995. Gene flow and population viscosity in Myrmica ants. Heredity 74:200-209.

SEPPÄ, P., AND L. WALIN. 1996. Sociogenetic organization of the red ant Myrmica rubra. Behav. Ecol. Sociobiol. 38:207-217.

SLATKIN, M. 1987. Gene flow and the geographic structure of natural populations. Science 236:787-792.

1993. Isolation by distance in equilibrium and non-equilibrium populations. Evolution 47:264-279.

Stille, M., AND B. STILle. 1993. Intrapopulation nestclusters of maternal mtDNA lineages in the polygynous ant Leptothorax acervorum (Hymenoptera: Formicidae). Insect Mol. Biol. 1:117121.

Sturtevant, A. H. 1938. Essays on evolution. II. On the effects of selection on social insects. Q. Rev. Biol. 13:74-76.

TAYLOR, P. D. 1992a. Altruism in viscous populations-An inclusive fitness model. Evol. Ecol. 6:352-356.

$1992 \mathrm{~b}$. Inclusive fitness in a homogeneous environment. Proc. R. Soc. Lond. B Biol. Sci. 249:299-302.

WEIR, B. S. 1996. Genetic data analysis II. Sinauer, Sunderland, MA.

Weir, B. S., And C. C. Cockerham. 1984. Estimating $F$-statistics for the analysis of population structure. Evolution 38:13581370.

Wilson, D. S., G. B. Pollock, and L. A. Dugatkin. 1992. Can altruism evolve in purely viscous populations? Evol. Ecol. 6: 331-341.

WRIGHT, S. 1943. Isolation by distance. Genetics 28:114-138.

Corresponding Editor: J. Carey 